\title{
EFFECT OF SPRAY DRYING ON PROTEIN CONTENT OF NATURAL RUBBER SERUM (NRS)
}

\author{
I. AIMI IZYANA AND M.N. ZAIROSSANI \\ Processing and Pollution Research Unit, Technology and Engineering Division, \\ Stesen Penyelidikan RRIM, Malaysian Rubber Board, \\ 47000, Sungai Buloh, Selangor Darul Ehsan, Malaysia.
}

izyana@lgm.gov.my,zairossani@lgm.gov.my

\begin{abstract}
Natural rubber latex comprises approximately $70 \%$ natural rubber serum (NRS) which is the aqueous part of the latex. The NRS is made up of mainly water and non-rubber components; sugar, protein and other lipids. The protein component of the NRS is separated using membrane separation and spray dried whereby the amino acid and protein content was monitored during the process. The optimum drying temperatures were first determined to obtain the maximum recovery of the protein powder, whereby the amino acid content was approximately 40 times that of the feed. The production of protein powder from NRS increases the rubber industry's competitiveness through value addition to the previously discarded NRS but also to the processing industry. NRS protein powder has a great opportunity to be developed as an alternative protein source.
\end{abstract}

ABSTRAK: Susu getah asli mengandungi lebih kurang 70\% serum getah asli (natural rubber serum (NRS)) iaitu bahagian susu getah yang berair. NRS sebahagian besarnya merupakan air dan komponen bukan getah; gula, protein dan lipid-lipid lain. Komponen protein NRS dipisahkan dengan menggunakan membran pemisah dan kaedah kering semburan dimana asid amino dan kandungan protein dipantau semasa proses tersebut. Pada mulanya, suhu pengeringan optimum ditentukan untuk mendapatkan hasil maksima serbuk protein, dimana kandungan asid amino adalah lebih kurang 40 kali suapan. Penghasilan serbuk protein daripada NRS meningkatkan daya saing industri getah dan industri pemprosesan menerusi pertambahan nilai terhadap NRS yang sebelum ini hanya dibuang. Serbuk protein NRS mempunyai peluang besar untuk dimajukan sebagai sumber protein alternatif.

KEY WORDS: proten; spray dry; natural rubber serum

\section{INTRODUCTION}

Natural rubber latex from the Hevea brasiliensis tree is made up of an emulsion of rubber particles suspended in aqueous phase. The aqueous phase, called serum, contains several non-rubber matters such as carbohydrates, proteins, lipids, minerals, microorganisms and water. Natural Rubber Serum (NRS) constitutes $60-70 \%$ of natural rubber latex, which normally contains 1 to $5 \%$ (w/w) of non-rubbers. Some of these non-rubbers are physically or chemically attached to the natural rubber component while others are dissolved in the serum. Some of the non-rubber substances such as lipids, carotenoid pigments, sterols, triglycerides, glycolipids and phospholipids can influence the final properties of rubber, such as compounded vulcanization characteristics and classical mechanical properties. 
Although some non-rubbers are useful for the properties of the product rubber, the majority serves no purpose and often constitutes a pollution problem when they end up in the effluent that results from the processing of latex and needs to be treated before discharged to the public waterways. In an effort to overcome this problem, a process was developed to recover and extract valuable biochemical from the NRS [1]. Table 1 shows the composition of non-rubber substances in NRS.

Table 1: Composition of Non-Rubbers in NRS [2].

\begin{tabular}{cc}
\hline Component & Amount (\% w/w of serum) \\
\hline Inositols & 2.38 \\
Proteins & 1.10 \\
Sugars & 0.40 \\
Free amino acid & 0.13 \\
Ascorbic Acid & 0.03 \\
Nitrogeneous bases & 0.06 \\
Glutathione & 0.02 \\
\hline
\end{tabular}

Protein is present in fresh Hevea brasiliensis latex to the extent of approximately 1$1.5 \%$ by weight, by which about half is associated with the rubber. It is generally recognized that the presence of protein in fresh latex is an important factor in controlling its colloidal stability. The proteins in the serum are separated and dried to produce the protein powder which has a potential to become animal feed or even nutrient media for cultivating microorganisms due to the presence of various amino acids [3] and phosphatides [4].

Utilization of non-rubber components in the NRS not only value adds to the rubber processing technology; but when integrated with membrane separation technology [5] can lead to a "zero discharge" scenario in the industry. Serum processing technologies are therefore imperative to be explored extensively in order to greatly benefit the industry and also the nation.

\section{MATERIALS AND METHODS}

\subsection{Sample Preparation}

Latex was first coagulated by adding $10 \%$ acetic acid until the $\mathrm{pH}$ of the latex reaches 4.2 and left overnight to ensure complete coagulation. The serum was obtained by creping the coagulum, where the serum was then filtered using a $0.2 \mu \mathrm{m}$ filter and subjected to membrane separation to separate the protein and sugar fractions of the serum. $70 \%$ of the serum was collected as permeate which is the sugar fraction. The rest $30 \%$; the retentate is the protein fraction. All the samples collected were stored at $4{ }^{\circ} \mathrm{C}$ to retain the integrity of the protein.

\subsection{Spray Drying}

The spray dryer used in this experiment is the pilot-scale Anhydro MS400 (Denmark). The protein fraction was first conditioned to room temperature before added into the spray dryer's feed tank. The drying temperatures were determined based on visual assessment of the product (free-flow and colour) where the inlet and outlet temperatures were varied. Once the best parameters were obtained, test runs were conducted to verify 
the validity of the previous assessment where the inlet and outlet temperatures, pressures, heater surface temperature and atomizer speed were monitored and recorded every 30 minutes.

\subsection{Analysis}

The protein powder produced was analyzed using Waters AccQTag to determine the amino acid content. The protein content was determined with the NI ${ }^{\mathrm{TM}}$ (NonInterfering ${ }^{\mathrm{TM}}$ ) Protein Assay by GBiosciences (USA).

\section{RESULTS AND DISCUSSION}

Previous research [6] for the lab scale production of the powder showed that the process developed is capable of producing stable protein powder with white appearance and has been successfully reproduced in the pilot-scale runs. The quality and characteristics of protein powder were dependent on several variables during processing particularly during the membrane separation and spray drying stages.

The protein content was monitored during the sample preparation, especially in the membrane separation to ensure proper concentration of the protein fraction to be subjected to spray drying. During the first trial of the pilot-scale spray dryer, the optimum inlet temperature was determined to be at $175^{\circ} \mathrm{C}$ while the outlet temperature at $95^{\circ} \mathrm{C}$ by varying the two temperatures while keeping the atomizer speed and pressure difference in the spray dryer constant. The powder produced was assessed visually for their freeflowing properties to determine the best temperatures (Table 2). All subsequent spray drying runs therefore are with the determined optimum temperatures.

The initial sample needs to be pre-conditioned before being subjected to spray drying in order to produce the best quality powder. Purification of the initial sample is important to have a successful spray dry run. Initial samples with low $\mathrm{pH}$ were found to produce sticky product (Table 3). Cleaning and proper maintenance of the spray dryer unit are vital to make sure future runs will yield the same result as previous runs.

Table 2: Determination of Optimum Spray Drying Parameters.

\begin{tabular}{llll}
\hline No & $\mathbf{T}_{\text {in }}$ & $\mathbf{T}_{\text {out }}$ & Powder \\
\hline 1 & 170 & 90 & Fine \\
2 & 180 & 90 & Not free-flowing \\
3 & 190 & 90 & Sticky \\
4 & 180 & 95 & Fine \\
5 & 170 & 95 & Fine and free-flowing \\
\hline
\end{tabular}

Table 3: Different pH in Initial Sample Affects Quality of Powder.

\begin{tabular}{llll}
\hline Run & pH & \% Brix & Powder \\
\hline 1 & 3.9 & 1 & Fine \\
2 & 4.7 & 1 & Fine and free-flowing \\
3 & 4.0 & 1.5 & Fine \\
4 & 3.5 & 1.1 & Not free-flowing \\
5 & 3.5 & 2.5 & Sticky \\
\hline
\end{tabular}


The protein content of the initial sample was determined using the Non-Interfering Assay and also enable the calculation of minimum powder recovery after spray drying (Table 4). Recovery of the powder depends on its free-flowing properties as high moisture content causes the product to stick to the surface of the bucket and render it difficult to collect the final product. Latex composition varies with each sample preparation, resulting in different protein concentration in different feed for the spray drying run.

From Table 5, the amino acid content in the powder was shown to be more than 40 times that of the acid in the initial sample. The dominant amino acid in both samples is Asp with more than $15 \%$ of the total content. Asp and Glu makes up for more than $25 \%$ of the amino acid content in both the initial sample and the powder. There is a theoretical loss of Ala and Val after spray drying.

The pilot-scale spray drying runs have therefore showed great promise in producing quality protein powder from NRS. However, future runs may be conducted with different feed i.e. samples from latex processing line in order to truly assess the feasibility of the process to be integrated with current rubber processing facilities.

Table 4: Protein Content of the Initial Sample and Powder Recovered.

\begin{tabular}{llll}
\hline Run & $\begin{array}{l}\text { Volume of Initial } \\
\text { Sample (L) }\end{array}$ & $\begin{array}{l}\text { Protein Concentration in Initial } \\
\text { Sample (g/L) }\end{array}$ & $\begin{array}{l}\text { Powder Recovered } \\
(\mathbf{g})\end{array}$ \\
\hline 1 & 19.1 & 6.77 & 290.93 \\
2 & 19.8 & 5.08 & 195.21 \\
3 & 22.5 & 3.33 & 257.50 \\
4 & 12.7 & 6.46 & 84.99 \\
5 & 20.75 & 2.69 & 67.14 \\
\hline
\end{tabular}

Table 5: Amino Acid Content Before and After Spray Drying.

\begin{tabular}{cccc}
\hline No & Amino Acid & Protein fraction & Protein powder \\
\hline 1 & Histidine & 0.012 & 0.765 \\
2 & Serine & 0.044 & 2.229 \\
3 & Arginine & 0.033 & 1.401 \\
4 & Glycine & 0.058 & 2.459 \\
5 & Aspartic Acid & 0.106 & 4.066 \\
6 & Glutamic Acid & 0.100 & 3.396 \\
7 & Threonine & 0.035 & 1.190 \\
8 & Alanine & 0.078 & 1.126 \\
9 & Proline & 0.032 & 1.718 \\
10 & Cysteine & 0.034 & 2.012 \\
11 & Lysine & 0.038 & 1.727 \\
12 & Tyrosine & 0.017 & 1.668 \\
13 & Valine & 0.056 & 0.899 \\
14 & Isoleucine & 0.019 & 0.711 \\
15 & Leucine & 0.055 & 2.031 \\
16 & Phenylalanine & 0.014 & 0.763 \\
\hline
\end{tabular}




\section{CONCLUSION}

Utilization of by-products of rubber processing particularly non-rubber components of the natural rubber latex for production of value-added biochemicals should be fully exploited to achieve "zero discharge" and to maximize revenue of the industry. Potential applications of the NRS protein powder are intended as industrial proteins and enzymes, culture growth media, feed additives and animal feed supplement.

NRS protein powder has a great opportunity to be developed as an alternative protein source. Furthermore the utilization of NRS directly benefits the rubber industry as it:

- Increase consumption of NR and provide new applications for latex.

- Improve competitiveness by reducing waste and generating value-added products.

- Enhances raw rubber factories through integration of NRS and latex processing (green industry).

- Minimizes environmental impact and cost of effluent treatment by utilizing NRS.

\section{ACKNOWLEDGEMENT}

The authors would like to thank the Processing \& Pollution Research Unit and the Malaysian Rubber Board for the work conducted. Assistance rendered by the PPRU staff, especially Mohd. Mustakiem, Fatin Syahirah, Mohd. Ikhwan and Hishamuddin are gratefully acknowledged.

\section{REFERENCES}

[1] Lau, C.M., Tajima, Y \& Machida, M "Natural Rubber Serum Concentrate and Method for making the same.” Malaysian Patent Appln. PI 8901670, 1998

[2] Zairossani M.N., Devaraj V., Mohd. Zin A.K. \& Zaid I "Modern Approaches Towards Effective Effluent Treatment" Proceedings of Rubber Planters' Conference 2005, Kuala Lumpur, 15-17 November 2005

[3] Whitby, G.S. \& Greenberg, H. (1941) "The Isolation of Amino Acids from Rubber Latex", 1941

[4] Smith, R.H. "The Phosphatides of the Latex of Hevea brasiliensis", 1953

[5] Devaraj V. \& Zairossani M.N "Zero Discharge and Value-Added Products from NR Skim Latex Processing" Malaysian Rubber Technology Development Vol 6 p18-21, 2006

[6] Zairossani, M.N "Production of Protein Powder from Natural Rubber Serum as a Source of Industrial Biochemicals", Technical brochure distributed at the 34rd International Exhibition of Inventions, New Techniques and Products, April 2006, Geneva, Switzerland, 2006 